\title{
Isolation, Selection and Identification of Polyaromatic Hydrocarbons (PAHs) Degrading Bacteria from Heavy Oil Waste (HOW)-Contaminated Soil
}

\author{
Mohamad Yani ${ }^{*}$, Charlena Charlena ${ }^{2}$, Zainal Alim Mas'ud ${ }^{2}$, Iswandi Anas ${ }^{3}$, Yadi Setiadi $^{4}$, Agung Dhamar Syakti $^{5}$ \\ ${ }^{1}$ Department of Agroindustrial Technology, Faculty of Agricultural Engineering and Technology, IPB University, Bogor, Indonesia \\ ${ }^{2}$ Department of Chemistry, Faculty of Mathematics and Sciences, IPB University, Bogor, Indonesia \\ ${ }^{3}$ Department of Land Resources Management, Faculty of Agricultural, IPB University, Bogor, Indonesia \\ ${ }^{4}$ Department of Silvy Culture, Faculty of Forestry, IPB University, Bogor, Indonesia \\ ${ }^{5}$ Marine Science and Fisheries Faculty-Raja Ali Haji Maritime University, Senggarang-Tanjungpinang, Indonesia
}

\section{ARTICLE INFO}

Article history:

Received December 12, 2017

Received in revised form November 30, 2019

Accepted January 5, 2020

\section{KEYWORDS:}

biodegradation,

bioremediation,

contaminated soil,

heavy oil waste,

$\mathrm{PAH}$

\begin{abstract}
The heavy oil waste (HOW) containing polyaromatic hydrocarbon (PAHs) is a persistent organic pollutants (POPs) that difficult to degrade. The new PAH degrading consortium was investigated from HOW contaminated soil in North Sumatera of Indonesia. The isolation, selection and identification of polyaromatic hydrocarbon degrading bacteria from soil contaminated by HOW was conducted to solve a bioremediation process. The isolation microbes from soil contaminated by HOW was performed using a minimum ONR7 a media and followed on marine agar media for purification purposes. From the performed isolation results, 11 isolates were able to degrade PAHs compounds, such as phenanthrene, dibenzothiophene, or fluorene compounds. They grew at $\mathrm{pH}$ range of 4.8-8.2 and performed on emulsification activity in paraffin from $0.150-0.662$. Three of them showed the best performance on HOW biodegradation capability and then successfully selected and identified as Salipiger sp., Bacillus altitudinis, and Ochrobactrum anthropi. using $16 \mathrm{~S}$ rDNA. The HOW biodegradation as TPH-degradation were $38.66 \%$, $59.60 \%$, and $47.16 \%$, respectively. Those isolated bacteria could potentially be as bioremediation agents to develop on bioremediation process for soils contaminated by HOW.
\end{abstract}

\section{Introduction}

Crude oil contains light and heavy oil fractions of total petroleum hydrocarbon (TPH). Heavy oil waste (HOW) contains polyaromatic hydrocarbons (PAHs). PAHs are relatively stable and recalcitrant in soil. Petrogenic PAHs are often marked as in abundance of alkyl substituted PAHs, such as alkyl naphthalenes, alkyl phenanthrenes, and alkyl dibenzothiophenes (Jong-Su et al. 2009). The content of hydrocarbons in the oil-polluted environment is relatively higher than the normal environment. In these circumstances, the survival microbes are that they capable to change the biochemical and molecular processes as an adaptive response to surrounding environmental changes. Little research in Indonesia was done to investigate potential bacteria for PAHs bioremediation. The bioremediation process of heavy oil waste could be done using a bacterial

\footnotetext{
* Corresponding Author

E-mail Address: moh.yani@apps.ipb.ac.id
}

consortium that degrade hydrocarbon compounds. The high quantity of bacterial species capable of degrading hydrocarbons is possibly related to the universal availability of hydrocarbons in nature.

Mao et al. (2012) reported that bioremediation of a PAH-contaminated soil by a bacterial consortium enriched from the soil. One of petroleum degrading microbe sources, which have been widely explored, is an environment contaminated by crude oil waste. Isolates dominating in this environment consist of several genera, namely, Alcaligenes, Arthrobacter, Acinetobacter, Nocardia, Achromobacter, Bacillus, Flavobacterium, and Pseudomonas. Ma et al. (2010) isolated Lysinibacillus sphaericus as a PAH-degrading bacterium from the rhizospheres of vegetation in a contaminated field. The PAH degrading bacteria of Pseudomonas, Marinobacter, Salinibacterium and Brevibacterium were isolated from polluted sediment samples (Isaac et al. 2013). A variety of bacterial strains in Acidovorax, Arthrobacter, Brevibacterium, Burkholderia, Comamonas, Mycobacterium, Pseudomonas, 
and Sphingomonas can utilize phenanthrene as a sole carbon (Jong-Su et al. 2009). Several bacteria able to use fluorene, such as Arthrobacter, Brevibacterium, Burkholderia, and Mycobacterium (Jong-Su et al. 2009).

This study used HOW-containing PAHs, which are persistent organic compounds that are difficult to degrade by microorganisms. Only certain bacteria that can degrade polyaromatic hydrocarbons compounds existing in the heavy fraction of petroleum waste. Therefore, in this study, we performed isolation, selection, and identification of PAHs degrading bacteria from soil contaminated with heavy oil waste (HOW) in a petroleum industries in Indonesia as tropical countries. We investigated a new consortium bacteria that capable to use PAHs as sole sources of carbon and energy. The consortium bacteria was identified as PAH degrading bacteria to be potential for bioremediation process of HOW.

\section{Materials and Methods}

\subsection{Soil Sampling}

Soils contaminated by HOW were taken from crude oil contaminated soils, and the HOW was provided by an oil and gas company at North Sumatera, Indonesia. The samples were taken at the site of soil-contaminated areas, such as soil, sludge, and rhizospheres of grass. The contaminated soils were transported at low temperatures and then were prepared for enrichment culture within 2 days.

\subsection{Enrichment Culture}

Approximately $50 \mathrm{~g}$ of soil contaminated by HOW was added to 11 of a general mineral media containing (mg/l): $\mathrm{FeSO}_{4} \cdot 7 \mathrm{H}_{2} \mathrm{O}(200), \mathrm{ZnSO}_{4} \cdot 7 \mathrm{H}_{2} \mathrm{O}(10), \mathrm{MnCl}_{2} \cdot 4 \mathrm{H}_{2} \mathrm{O}$ (3), $\mathrm{CoCl}_{2} \cdot 6 \mathrm{H}_{2} \mathrm{O}$ (20), $\mathrm{CuCl}_{2} \cdot 2 \mathrm{H}_{2} \mathrm{O}(1), \mathrm{NiCl}_{2} \cdot 6 \mathrm{H}_{2} \mathrm{O}(2)$, $\mathrm{Na}_{2} \mathrm{MoO}_{4} \cdot 2 \mathrm{H}_{2} \mathrm{O}(500), \mathrm{H}_{3} \mathrm{BO}_{3}(30)$, and $5 \mathrm{ml}$ of diesel oil $(\% \mathrm{v} / \mathrm{v})$ as the carbon source. The use of diesel oil was for microbial consortium adaptation before using HOW. Enrichment cultures were conducted at room temperature $\left(25-30^{\circ} \mathrm{C}\right)$ and were aerated for 2 weeks. The enrichment cultures were transferred to fresh media and $5 \%$ HOW was added as the carbon source. During enrichment cultures, the $\mathrm{pH}$ was maintained at $\mathrm{pH}$ 6-8 using $\mathrm{H}_{2} \mathrm{SO}_{4} 8 \mathrm{~N}$ or $\mathrm{NaOH} 6 \mathrm{~N}$. After several weeks, the HOW would be degraded by the consortium of bacteria.

\subsection{Isolation of Hydrocarbon-degrading Bacteria}

As much as $1 \mathrm{ml}$ of the enrichment culture was diluted $10^{5}$ times with saline solution $(0.85 \%$ sterile $\mathrm{NaCl})$ and then inoculated by the pour plate method using nutrient agar (NA) and marine agar (MA) from Difco. Each plate was labeled based on the medium type. The plates were incubated upside down at $30^{\circ} \mathrm{C}$ for one week. Observation of new colonies was performed every day.
Each colony grown was coded then isolated by using minimum ONR7a medium and then PAH compounds (phenanthrene, dibenzothiophene, and fluorene) were added by using the sublimation technique. The ONR7a medium contained mineral medium that described by Syakti et al. (2013). Phenanthrene, dibenzothiophene, and fluorene were used as a contaminant model and then were enriched in the ONR7a medium as the sources of carbon and energy at a final concentration of 0.4 $\mathrm{mg} / \mathrm{l}$. The sublimation technique was conducted by heating phenanthrene, dibenzothiophene, and fluorene compounds. The evaporating PAH compounds would sublimate and were caught in ONR7a media given by cooling ice cubes. After finding the clear zone around the potential cultures, which were isolated, aseptically the evaporating PAH compounds were inoculated back into ONR7a media. Incubation was carried out at ambient temperature for $24-72 \mathrm{~h}$. Then, refining was performed by using streak plates with MA media. The pure isolates were confirmed to ensure the selected culture's ability to degrade PAHs by subculturing into $5 \mathrm{ml}$ of liquid medium containing $5 \mathrm{mg}$ ONR7a of crystalline phenanthrene, dibenzothiophene, and fluorene compounds.

\subsection{Selection of Bacterial Isolates}

The obtained isolates were selected based on their ability to survive and grow on media containing HOW ( $5 \%$ in mineral media), as well as the ability to degrade heavy oil waste. Microbe selection was performed based on the ability to lower $\mathrm{pH}$, to increase the microbial population and percentage of oil biodegradation in minimal media with carbon sources from HOW. All isolate cultures were incubated at $30^{\circ} \mathrm{C}$ for 3 weeks and the changing in number of population, $\mathrm{pH}, \mathrm{TPH}$ (solid), and COD in slurry was observed after $0,3,7,14$, and 21 days. Two cultured replicates were taken and separated of the sludge (solid phase) and liquid phase. The solid phase was measured for oil content as total petroleum hydrocarbon (TPH) by solvent extraction methods (3540C EPA). The liquid phase was measured for population of bacteria using the TPC method, $\mathrm{pH}$, and COD (Clesceri et al. 2005). The biodegradation of TPH was calculated from the results of TPH content of the slurry phase of HOW.

\subsection{Biodegradation Test}

The bacteria existing in HOW that potentially degrade PAH compounds were confirmed by the sublimation technique using minimum ONR7a media. The ability of bacteria to degrade PAHs was indicated by the clear zone on the phenanthrene compound and the discoloration on dibenzothiophene compounds. After finding the clear zone and discoloration around potential cultures that had been isolated, the potential cultures were 
aseptically re-inoculated to ONR7a media. Incubation at ambient temperature was conducted for 24-72 h, and then the bacteria were transferred back to minimum ONR7a media. The purity of cultures were tested by planting in rich medium (Marine Agar medium, Difco). The pure isolates were subcultured into $5 \mathrm{ml}$ of liquid ONR7a media containing $5 \mathrm{mg}$ crystalline phenanthrene, dibenzothiophene and fluorene compounds. The confirmation test was conducted to ensure the ability of selected cultures to degrade PAHs.

\subsection{Emulsification Activity Measurement Using Solid Paraffin}

Emulsification activity was measured by using the method of Johnsons et al. (1992). The pure isolates were measured by using compact paraffin. A $4.5 \mathrm{ml}$ supernatant was added to $0.5 \mathrm{ml}$ hydrocarbon (solid paraffin). After mixing for 1 minute, they were incubated for $2 \mathrm{~h}$ and the emulsion stability was measured using the OD at $610 \mathrm{~nm}$. The controls consisted of mineral water and hydrocarbons.

\subsection{Identification of Selected Pure Cultures of Degrading Hydrocarbon}

The selected isolates were identified molecularly (16s rDNA), as commonly reported. The molecular analysis performed included DNA extraction, PCR amplification, PCR product purification, and sequencing as follows.

DNA Extraction was performed by the Intragene Matrix kit(BioRad, Germany), followed by amplification. The PCR optimization results were obtained using primer 9F (5'-GAGTTTGATCCTGGCTCG-3') and $1510 \mathrm{R}$ (5'-GGCTACCTTGTTACGACTT-3'). PCR was performed in a thermal cycler (T Shuzo) for 35 cycles. The initial step was at $94^{\circ} \mathrm{C}$ for 5 minutes, followed by 35 cycles consisting of $1 \mathrm{~min}$ denaturation at $94^{\circ} \mathrm{C}, 1 \mathrm{~min}$ annealing at $56^{\circ} \mathrm{C}$, and 2 min extension at $72^{\circ} \mathrm{C}$. After 35 cycles were completed, a final amplification for $4 \mathrm{~min}$ at $72^{\circ} \mathrm{C}$, and cooling at $4^{\circ} \mathrm{C}$ for 30 min completed the reaction. The amplification results were fractionated by electrophoresis on a Mupid Mini Cell (Exu) 1\% agarose gel in TEA buffer (Tris-EDTA) for $20 \mathrm{~min}$ at $100 \mathrm{~V}$. The gels were incubated with ethidium bromide solution with a concentration of $1 \mathrm{ml} / 100 \mathrm{ml}$ for $15 \mathrm{~min}$. The results were visualized on a Gel Doc Printgraph (Bioinstrument, ATTO) using a UV transilluminator using the standard 100 bp DNA ladder (Promega) to determine the result and size of the DNA bands of the amplification results.

DNA purification of the PCR results was performed by precipitation. 0.1 and 2 times the total volume of 3 $\mathrm{M} \mathrm{Na}$-acetate $\mathrm{pH} 5.2$ and $95 \%$ ethanol were added to the amplified PCR samples and then cooled at $-20^{\circ} \mathrm{C}$ for 1 hour. Next, the samples were centrifuged at $10,000 \times \mathrm{g}$ for $30 \mathrm{~min}$. The supernatant was discarded and the pellet was washed with $85 \%$ ethanol and then re-centrifuged at $10,000 \times \mathrm{g}$ for over $45 \mathrm{~min}$. The supernatant was discarded and the pellet was precipitated at room temperature. The DNA pellet was dissolved with 15 $\mu$ of deionized water.

The next stage was cycle sequencing using the single primer, $9 \mathrm{~F}$. The composition used for each tube was 1 $\mathrm{ml} 5 \mathrm{pmol}$ primer, $150 \mathrm{ng}$ purified DNA, $0.2 \mu \mathrm{l}$ Big Dye Terminator sequences premix kit(Applied Biosystems), $2 \mathrm{ml}$ of $5 \mathrm{X}$ buffer sequences and deionized water to volume of $10 \mathrm{ml}$. PCR amplification was then performed with a total of 30 cycles. The initial step was at $96^{\circ} \mathrm{C}$ for $20 \mathrm{sec}$, followed by cycles consisting of $10 \mathrm{sec}$ denaturation at $96^{\circ} \mathrm{C}$, annealing $5 \mathrm{sec}$ at $50^{\circ} \mathrm{C}$, and 4 min extension at $60^{\circ} \mathrm{C}$.

Preparation was conducted by mixing $10 \mathrm{ml}$ product cycle sequencing with $1 \mathrm{ml}$ of $3 \mathrm{M} \mathrm{Na}$-acetate and $25 \mu \mathrm{l}$ absolute ethanol, vortexing and then allowed to stand for $15 \mathrm{~min}$. The samples were then centrifuged at $16,000 \times \mathrm{g}$ for $20 \mathrm{~min}$ at room temperature. The supernatant was discarded and the pellet was washed with $70 \%$ ethanol and then re-centrifuged at $16,000 \times \mathrm{g}$ for 5 minutes. The supernatant was reset and the pellet was precipitated for 5 minutes. $15 \mu \mathrm{l} \mathrm{Hidi-Formamide}$ (Applied Biosystems) was added to the dried DNA pellet and was vortexed. The samples were then heated to $95^{\circ} \mathrm{C}$ for $2 \mathrm{~min}$ and immediately cooled on ice. In the next phase, the samples were injected to the sequencer ABI 3130 model (Applied Biosystems).

The BioEdit program was used for DNA analysis and blast in the NCBI data Library Gene Bank was performed. The phylogenetic analysis used multiple alignment programs of Clustal $X$ version 1.83 . The phylogenetic tree construction was based on genetic distances kinship with the neighbor joining method. The 16S sRNA sequences of three isolates were submitted to the European Nucleotide Archive (ENA); EMBL Nucleotide Sequence Database <datasubs@ebi.ac.uk> and registered at http://www.ebi.ac.uk/ena/data/view/ LT708299-LT708301.

\section{Results}

\subsection{Isolation of Hydrocarbon-degrading Bacteria}

The result of enrichment culture appeared several kinds of PAH degrader (Tabel 1). Each isolated PAH degrader were tested to growth on media containing of phenanthrene (Phe), dibenzothiophene (Dbt), and fluorene (Flr) compounds as carbon sources. Emulsification activity was measured by using the method of Johnsons et al. (1992). The test results of the emulsification activity from the supernatants are shown in Table 1. 
Table 1. Confirmation test of isolates using phenanthrene (Phe), dibenzothiophene (Dbt), and fluorene (Flr) compounds, and emulsification activity in paraffin

\begin{tabular}{lccccc}
\hline \multirow{2}{*}{ Isolate code } & \multicolumn{2}{c}{$\begin{array}{l}\text { Growth oberserved } \\
\text { in PAHs compounds }\end{array}$} & \multirow{2}{*}{$\begin{array}{c}\text { Emulsification } \\
\text { activity }\left(\mathrm{OD}_{610}\right)\end{array}$} \\
\cline { 2 - 4 } & Phe & Dbt & Flr & \\
\hline MY 1 & + & - & - & 0.463 \\
MY 3 & + & - & - & 0.592 \\
MY 5 & - & + & - & 0.465 \\
MY 6 & + & + & - & 0.427 \\
MY 7 & + & + & - & 0.662 \\
MY 8 & - & + & + & 0.437 \\
MY 9 & - & + & - & 0.150 \\
MY10 & - & + & - & 0.286 \\
MY11 & - & + & - & 0.421 \\
MY12 & - & + & - & 0.189 \\
MY13 & - & - & + & 0.318 \\
\hline
\end{tabular}
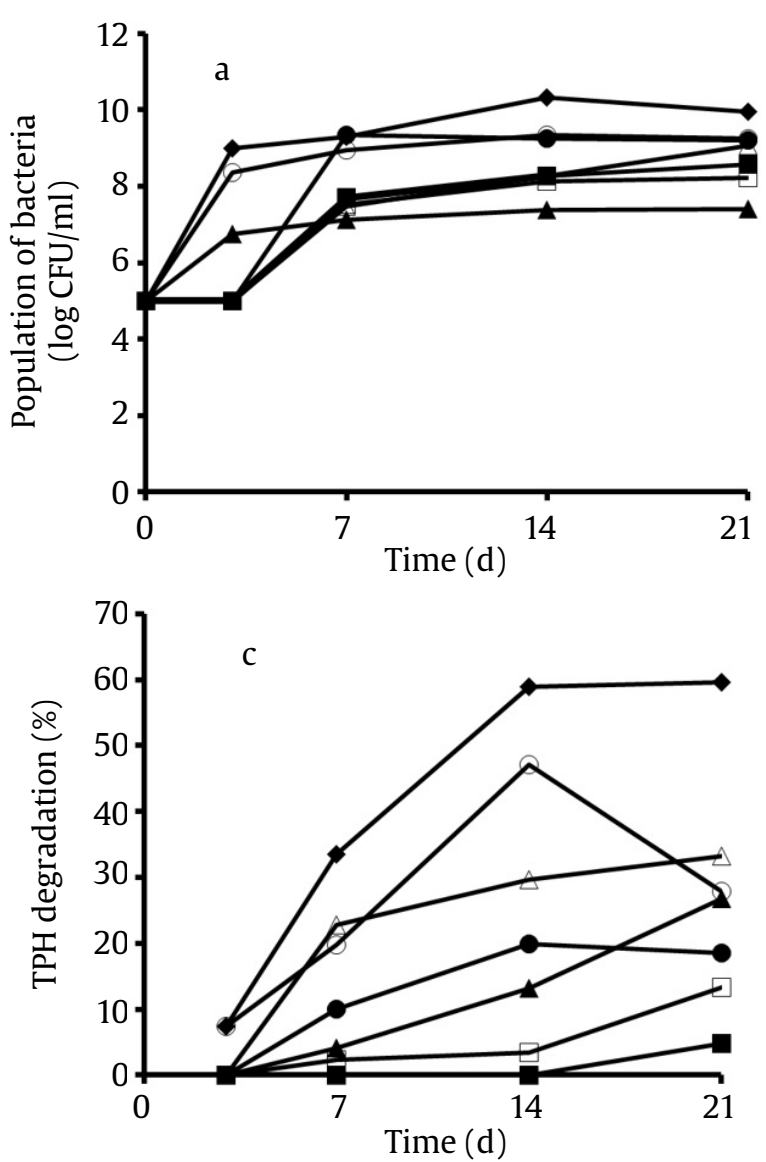

\subsection{The Growth of Selected Isolates}

Figure 1 show the growth of isolated bacteria on mineral media containing 5\% HOW. All isolates can degrade the HOW and well grow. The 3 of isolated bacteria were selected base on their growth characteristics and identified by $16 \mathrm{~S}$ rDNA methods.

\subsection{Identification of Hydrocarbon-degrading Bacteria}

The 3 of 11 isolated bacteria were identified by $16 \mathrm{~S}$ rDNA (Table 2) and the sequence of DNA were deposited at www.ebi.ac.uk. The phylogenetic neighborhood of the three isolated bacteria in a $16 \mathrm{~S}$ rDNA gene sequence based tree is presented in Figure 2.
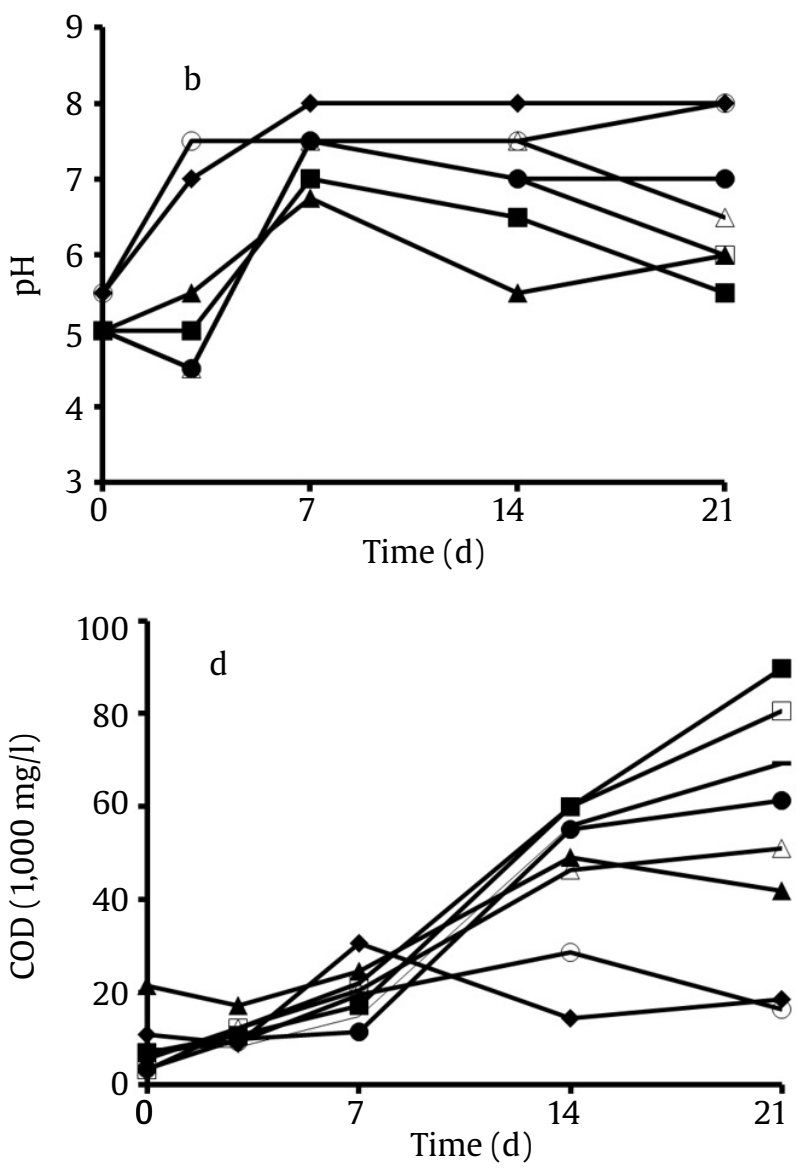

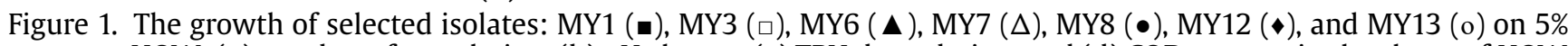
HOW; (a) number of population, (b) pH change, (c) TPH degradation, and (d) COD content in the slurry of HOW 
Table 2. Identification molecular of 3 superior isolates

\begin{tabular}{lcccc}
\hline Isolate code & Assession number* & Length of 16S rDNA (bp) & Nearest bacteria taxon of BLAST & Homology (\%) \\
\hline MY7 & LT708299 & 1027 & Salipiger sp. PR55-4 & 100 \\
MY12 & LT708300 & 1241 & Bacillus altitudinis & 97 \\
MY13 & LT708301 & 1502 & Ochobactrum anthropi & 97 \\
\hline
\end{tabular}

*http://www.ebi.ac.uk/ena/data/view/LT708299-LT708301

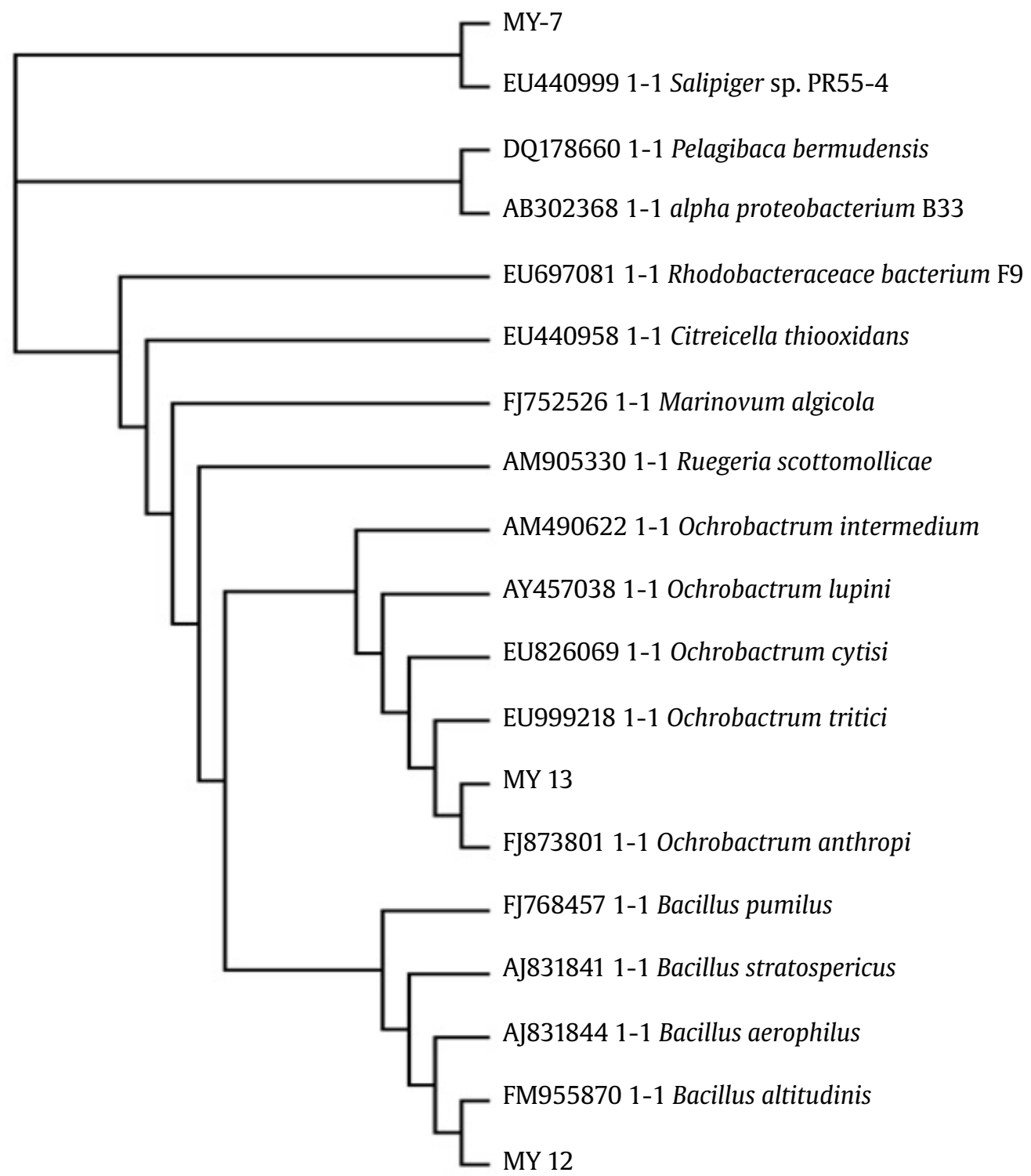

Figure 2. Phylogenetic neighborhood of three isolated bacteria in a 16S rDNA gene sequence based tree

\section{Discussion}

\subsection{Isolation of Hydrocarbon-degrading Bacteria}

The hydrocarbon-degrading bacteria were isolated from a bacterial consortium derived from soil contaminated by HOW. The population of bacteria from samples with the Total Plate Count (TPC) method was $1.12 \times 10^{8} \mathrm{CFU} / \mathrm{ml}$. The cultured colonies are from consortium bacteria that are suggested to use PAHs as carbon sources. Charlena et al. (2010) reported that a consortium bacterium was used for bioaugmentation of soil contaminated by HOW by the land farming method. The consortium bacteria from heavy residual fuel oil (Beškoski et al. 2011) and PAH-contaminated soil (Mao et al. 2012) were reported as PAH degraders. 
Through preliminary observation, we suggested that some colonies have a good affinity for PAHs (phenanthrene, dibenzothiophene, and fluorene), hence, their potential ability to degrade pollutants. The concentration of cells, which possibly enables degradation of hydrocarbons, was $1 \times 10^{6} \mathrm{CFU} / \mathrm{g}$ to $1 \times 10^{8} \mathrm{CFU} / \mathrm{g}$. The bacteria existing in HOW that potentially could degrade $\mathrm{PAH}$ compounds were confirmed by the sublimation technique using minimum ONR7a media. The ability of bacteria to degrade PAHs was indicated by the clear zone of phenanthrene compound and discoloration of dibenzothiophene compounds. Of the colonies that appeared on the plates, 11 isolates were selected and confirmed to use PAHs (Table 1). Four isolates (MY1, MY3, MY6, and MY7) degraded phenanthrene (Phe). Eight isolates (MY5, MY6, MY7, MY8, MY9, MY10, MY11, and MY12) degraded dibenzothiophene (Dbt). Two isolates (MY8 and MY13) degraded fluorene (Flr).

\subsection{Emulsification Activity Measurements Using Solid Paraffin}

From the spectrophotometry results with a wavelength of $610 \mathrm{~nm}$, all isolates produced surfactants that could emulsify solid paraffin and indicated the optical density from 0.150-0.662. The isolates of MY8 that degrade dibenzothiophene and fluorene showed an optical density at 0.437 . While the isolate of MY13 that degrades fluorene had an optical density at 0.318 . The isolates of MY7 had the ability to dissolve solid paraffin larger than the other isolates (0.662). The isolates of MY7 is consistent with the ability of this isolate, which also has the ability to degrade phenanthrene and dibenzothiophene. The emulsified organic compounds contained an intermediate product from paraffin degradation described by Cerniglia (1992).

\subsection{Selection of Hydrocarbon Compound Degrading Bacteria Isolates}

The ability of bacterial isolates to degrade hydrocarbons contained in heavy oil waste (HOW) was performed to select isolates, which would be used for further processing by observing isolates that had the best performance, which could be observed from the smallest TPH. By gas chromatography analysis, the chromatogram of HOW contained at least from $\mathrm{C}_{6}-\mathrm{C}_{22}$ of alkane and polyaromatic compounds (data not shown).
After obtaining 11 isolates, the selection process was performed on the isolates having the ability to degrade dibenzothiophene compound i.e., isolates with codes MY5, MY9, MY10, MY11, and MY12. Of the 5 isolates, the MY12 isolate had a better ability to degrade hydrocarbons with TPH of $0.26 \%$. The selection was conducted on the seven other isolates having the ability to degrade phenanthrene, dibenzothiophene, and fluorene compounds. Of the selection of isolates, MY1, MY3, MY6, MY7, MY8, MY12, and MY13, we selected 3 isolates with the best performance. The 7 isolates were incubated for 3 weeks and observed every week to measure the change in bacterial growth, $\mathrm{pH}$ media, TPH in soil/ sediment, and COD of cultured media.

\subsubsection{The Growth of Isolates}

Figure 1 a shows the growth of 11 isolates in $5 \%$ HOW. Three isolates, MY12, MY13, and MY6, demonstrated direct adaptation for growth, while others strains showed 3 days of the latent phase. The growth of MY8 is the same as MY12 after 7 days of inoculation. By day 21, the number of cells in each isolate continued to grow steadily. The number of cells in each single isolate was optimum at different times (Figure 1a). Isolates, MY1, MY7, and MY8, optimally grew on day 21 , while other isolates optimally grew on day 14 . The optimum growth of bacterial cells would increase the rate of degradation of hydrocarbons or would decrease the value of TPH in heavy oil waste.

Heavy oil waste contained toxic compounds with high concentrations so that isolates required a longer time to adapt to the environmental conditions. We observed MY12, which showed the best cell growth, since it had the highest number in population. Such argument was supported that the visualization of the growth of the isolates showed that the MY12 culture had more cloudiness in its medium, compared to the other isolates.

\subsubsection{Changes in $\mathbf{p H}$}

The size of the population of bacteria was influenced by the environmental $\mathrm{pH}$ conditions. If the $\mathrm{pH}$ was in the normal range or neutral, the cell growth would grow well (Figure 1b). The optimum number of cells would enhance the ability of isolates in degrading hydrocarbons. The increase in the level of degradation was indicated from a decrease of the TPH value for each day. On day 0 and day 3 , single isolates did not tend to demonstrate its ability to 
lower TPH. This was caused by the low pH values on day 0 and 3 with values ranging between 4.5 and 6.5 (Figure $1 \mathrm{~b}$ ). The low pH values would cause stunted isolates. This could be seen from the population of bacteria on day 0 and day 3, the isolate cell growth was still very low. After 3 days, the $\mathrm{pH}$ value increased or decreased after the $\mathrm{pH}$ value was neutralized. If in the biodegradation process there was either an increase or decrease of $\mathrm{pH}, \mathrm{pH}$ was controlled by adding $\mathrm{NaOH}$ or $\mathrm{HCl}$ until the $\mathrm{pH}$ became normal or neutral ( $\mathrm{pH} 7$ ).

\subsubsection{TPH Degradation}

The TPH value became a reference in determining the best three hydrocarbon-degrading isolates. The initial TPH of the slurry (solid) phase ranged from 17.2-23.2\%. The more significant decrease in TPH indicated the better ability of isolates in degrading hydrocarbons in heavy oil waste. Based on the TPH degradation value, the best two isolates in the biodegradation process were MY7 and MY12 (Figure 1c). The highest degradation level of TPH by MY12 on day 21 was $59.60 \%$ (Figure 1c), with a final TPH value of $7.64 \%(\mathrm{w} / \mathrm{w})$ of the initial TPH at $18.91 \%(\mathrm{w} / \mathrm{w})$. The most drastic decrease in TPH occurred on day 14, and then there was a constant decrease in TPH. This was observed from the number of MY12 cells on day $12-14$, which were the largest at $2.2 \times 10^{10} \mathrm{CFU} / \mathrm{ml}$. This showed that the greater number of cell isolates indicated the greater the TPH degradation occurred.

The second-best isolate was MY13 with a TPH degradation level of $38.66 \%$ (Figure 1c) with the final TPH value of $15.71 \%$ of the initial TPH of $24.43 \%$. The higher the TPH degradation level, the better ability of isolates in degrading petroleum hydrocarbons. The TPH degradation level was optimum at different times. This was due to the different adaptability of each isolate.

Adaptability of isolates was demonstrated by the population of bacteria. The increase in the TPH value occurring in the biodegradation process was caused by the bacteria, which had passed through the stationary phase resulting in decreases not only in the number of bacterial cells, but also the ability of degrading hydrocarbons. The anomalous degradation level of TPH occurred in MY12 because the hydrocarbon content in HOW was uneven, so the difference in total hydrocarbons caused a negative value.

\subsubsection{COD Value}

The emulsified organic compounds and intermediate $\mathrm{PAH}$ degradation products in cultured isolates were measured as chemical organic compounds (COD). Figure $1 \mathrm{~d}$ shows the COD value in liquid media where it represented the organic compounds released from soil contaminated by HOW. The biosurfactant produced by bacteria will enhance to disperse or release the organic compound from soil matrices to the liquid phase. The COD value increased during the incubation period, however after 1421 days, the COD value fluctuated in accordance to bacterial activity on degradation and mineralization to simple products. The MY12 isolate had the lowest COD value compared with other single isolates (Figure 1d). The low COD value indicated that the organic compounds contained in the sample (liquid phase) were fewer; this was in line with the highest in TPH degradation (Figure 1c) by the MY12 isolate. From the observed parameters, isolates, MY7, MY12, and MY13, had a better ability to degrade heavy oil waste (Figure 1c). These three isolates were further identified to determine the bacterial species contained in each.

\subsection{Identification of Isolates MY7, MY12 and MY13}

The identification of bacteria was performed molecularly, based on genetic analysis, part of the $16 S$ ribosomal bacterial DNA. Isolation of DNA was preceded by growing bacterial isolates in Marine agar media and then incubating for $72 \mathrm{~h}$. Bacterial DNA extraction was conducted by using the GES method (Picher et al. 1989).

PCR amplification included Primer20 $\mathrm{F}$ (5'-GATTTTGATCCTGGCTCAG-3') and 1500 R (5-GTTACCTTGTTACGACTT-3'). The PEG precipitation method was performed on the purified PCR samples (Hiraishi et al. 1995) and then followed by cycle sequencing with primers 520 F (5'-GTGCCAGCAGCCGCGG-3'), and 920 R (5'-GTCAATTCCTTTGATTT-3'). The resulting cycle sequencing samples were purified again with the ethanol purification method. The reading analysis of nitrogen base sequences was performed with an automated DNA sequencer (ABI PRISM 3130 Genetic Analyzer).

The raw data in the subsequent sequencing results were processed in Trimming with the program, MEGA 4, and assembling with the BioEdit program and 
further converted to the fasta format. The results of DNA sequencing in fasta format were then processed in blast to search for homology in the DNA data base center in the DDBJ (http://www.ddbj.nig.ac.jp). Table 2 shows the results of the molecular identification of the 3 superior isolates and Figure 2 shows the phylogenetic neighborhood of the three isolated bacteria by a 165 rDNA gene sequence based tree.

The MY7 isolate (accession no. LT708299) is $100 \%$ homologous to Salipiger sp. PR55-4 (accession no. EU440999) (Table 2 and Figure 2). This result showed high sequence similarity to Pelagibaca bermudensis (D0178660), Alpha proteobacterium B33 (AB302368), and Rhodobacteraceae bacterium F9 (EU69708), respectively. The Salipiger sp. PR554 is gram-negative and rod-shaped, is included in chemoheterotrophic aerobic bacteria (cannot grow under anaerobic conditions), has resulting catalase and phosphatase enzymes, and does not produce acid from carbohydrates; they are also not able to grow with carbohydrates or amino acids as a sole source of carbon and energy. Salipiger mucescens is a gramnegative rod isolated from a hypersaline habitat. This species is chemoheterotrophic and strictly aerobic, moderately halophilic, and is exopolysaccharide producing (Martínez-Cá novas et al. 2004).

From the confirmatory test performed, the MY7 Salipiger sp. can degrade phenanthrene and dibenzothiophene (Table 1), optimum growth is at pH 5-8 (Figure 1b), and HOW degradation reached $33.19 \%$ at 21 days (Figure 1c). The isolates of MY7 Salipiger sp. can use sole carbon as a source from palm oil, kerosene, diesel oil, and HOW (data not shown). This bacterium had similar growth to others isolated by some authors. Salipiger nanhaiensis was isolated from the deep-sea water in China (Dai et al. 2015). Related cross phylogenicity of Roseobacter is Roseovarius sp., that is coco-shaped, forms small raised creamy colonies on nutrient agar medium, and can degrade $<15 \%$ of phenanthrene after 10 days. The maximum biodegradation efficiency of $28.4 \%$ was obtained at $\mathrm{pH}=8.2$, temperature $\approx 35^{\circ} \mathrm{C}$, salinity $=30 \mathrm{ppt}, \mathrm{NH}_{4} \mathrm{Cl}=0.13 \mathrm{~g} / \mathrm{l}$ and inoculum size $=0.2$ OD $600 \mathrm{~nm}$. The abiotic elimination of phenanthrene during bio-degradation experiments was negligible (Shahriari et al. 2013).

The isolate of MY12 (accession no. LT708300) is 97\% homologous to Bacillus altitudinis (FM955870) (Table 2 and Figure 2). This result showed high sequence similarity to Bacillus aerophilus (AJ831844), Bacillus stratosphericus (AJ831841), and Bacillus pumilus (FJ768457), respectively. From the confirmatory test performed, the Bacillus altitudinis MY12 bacteria can degrade dibenzothiophene (Table 1), optimum growth is at pH 5.5-8.2 (Figure $1 \mathrm{~b}$ ), and the highest of HOW degradation reached $59.6 \%$ at 21 days (Figure 1c). The isolates of MY12 Bacillus altitudinis can use sole carbon as a source from palm oil, kerosene, diesel oil, and HOW (data not shown). Bacillus altitudinis are rodshaped, gram-positive bacteria (Shivaji et al. 2006), which can only degrade dibenzothiophene. B. pumilus has a kinship with $B$. altitudinis, having the ability to degrade naphthalene compounds found in petroleum waste (Calvo et al. 2004). Bacillus altitudinis DHN8 isolated from a compost pit was assessed for xylanase production by utilizing a sorghum straw (Adhyaru et al. 2014). The bacterium, Bacillus altitudinis AP-MSU, is able to produce esterase and was isolated from the gut of the marine fish, Sardinella longiceps (Esakkiraj et al. 2012).

The isolate of MY13 (accession no. LT708301) is $97 \%$ homologous to Ochrobactrum anthropi (FJ873801) (Table 2 and Figure 2). This result showed high sequence similarity to Ochrobactrum cytisi (EU826069), Ochrobactrum tritici (EU999218), Ochrobactrum lupini (AY457038), and Ochrobactrum intermedium (AM 490622). From the confirmatory test performed, the Ochrobactrum anthropi MY13 bacteria can degrade fluorene (Table 1), has an optimum growth at pH 5.5-8.2 (Figure $1 \mathrm{~b}$ ), and the highest of HOW degradation reached $47.16 \%$ at 14 days (Figure 1c). The isolates of MY13 Ochrobactrum anthropi can use sole carbon as a source from diesel oil and heavy oil waste (HOW), but it cannot grow in media containing palm oil and kerosene (data not shown). The isolate of Ochrobactrum anthropi MY13 will be utilized in future studies.

The genus, Ochrobactrum, belongs to the family, Brucellaceae, within the alphaproteobacterial order, Rhizobiales. Ochrobactrum strains were isolated from diverse habitats including soil, plants and their rhizospheres, wastewater, animals and humans (Bathe et al. 2006). This is the first finding of Ochrobactrum anthropi MY13 in soil contaminated by HOW. In medical science, the first reported case was in Malaysia of a catheter-related bloodstream infection caused by Ochrobactrum anthropi in a patient with underlying diabetes and ESRF (Rohani and Tzar 2013). Seven methyl parathion-degrading bacteria were isolated from long-term methyl parathion- 
contaminated soil and were found as one of genera to belong to Ochrobactrum (Zhang et al. 2005).

Ochrobactrum strains are of particular interest for bioremediation (Bathe et al. 2006). They are capable of degrading organophosphorus pesticides, such as parathion and methyl parathion (Zhang et al. 2005), petroleum waste (Katsivela et al. 2005), fungicide chlorothalonil (Kim et al. 2004), phenol (El-Sayed et al. 2003), and the toxic organic solvent dimethylformamide (DMF) (Veeranagouda et al. 2006). Ochrobactrum anthropi YD50.2. denitrified $\mathrm{NO}_{2}-$ or $\mathrm{NO}_{3}-$. The gene clusters for denitrification (nar, nir, nor, and nos) were cloned from 0 . anthropi YD50.2, in which the nir and nor operons were linked (Doi et al. 2009). These results have generated considerable interest in the application of 0 . anthropi as a bioremediation agent.

Many researchers isolated the petrophylic hydrocarbon degraders from different environments. The petrophylic hydrocarbon degraders spread throughout the world-wide environment from Asia, Europe, America and Africa, which are isolated from soil-contaminated areas, hypersaline habitats, deep sea water, polluted sediments, mangrove sediments, agricultural soils, etc. (Table 3 ). We reported that the petrophylic consortium bacteria were successfully isolated and identified from soil contaminated by heavy oil waste (HOW) that contain polyaromatic hydrocarbon compounds in Indonesia.

\subsection{Future Applications}

The soil or sediment contaminated by crude oil or bioremedied soil contains a heavy $\left(\mathrm{C}_{24}-\mathrm{C}_{40}\right)$ fraction of TPH. Rosenberg and Ron (1998) described the bioremediation of petroleum contamination by several methods, such as land farming. The oil and gas company that operates in Indonesia generally treat the crude oil-contaminated soil by land farming and biostimulation of indigenous consortium microorganisms with fertilizer (N, P, $\mathrm{K})$. These bioremediation methods achieve the high biodegradation rate at several weeks, then slow down for several months. At the end of the land farming process, the bioremedied soil reaches a residual TPH between $2-4 \%$, and then it becomes very difficult to decrease to comply to the Indonesian regulation at $1 \% \mathrm{TPH}$. The bioremedied soil is further treated by phytoremediation to degrade the residual TPH and heavy metals. Arifudin et al. (2016) reported that bioremediation of crude oil-contaminated soil by consortium bacteria decreased the TPH from $4.22 \%$ to approximately $1 \%$. After analyzing the bioremedied soil by chromatography GCMS, the chromatogram shows that high molecular weights (>C17) dominated the PAH.

Many researchers are interested in contributing to findings of PAH degraders from many sources to treat sediment and soil contaminated by PAH (Table 3). Cerniglia (1992) reported three main pathways for PAH degradation by fungi and bacteria. Those bacteria are indigenous consortium microbes, because the consortium bacteria will work to degrade or oxidize the target compounds by extracellular enzymes.

Beškoski et al. (2011) reported that the mazut (heavy residual fuel oil)-polluted soil was exposed to bioremediation in an ex situ field-scale study by biostimulation and bioaugmentation with microbial consortia. The reductions for the aliphatic, aromatic, and nitrogen-sulfur-oxygen and asphaltene fractions are $96 \%, 97 \%$, and $83 \%$, respectively. However, the isoprenoids, pristane and phytane, were more than 55\% biodegraded. Mao et al. (2012) reported that bioremediation of PAH-contaminated soil (90.6\% of which were 4- and 5-ring PAHs) was carried out for 56 days and showed at $35.8 \%$ of total PAHs were removed from the soil with the addition $20 \%$ of a bacterial consortium suspension.

This research shows that the indigenous isolated bacterial play a role in PAH biodegradation of HOW. The three new isolates of Salipiger sp. MY7, Bacillus altitudinis MY12, and Ochrobactrum anthropi MY13 were isolated from soil contaminated by HOW. They can degrade PAH compounds of phenanthrene, dibenzothiophene, and fluorene. The mixed culture of three isolates may synergistically work on biodegradation of heavy oil waste. This bacterial consortium may be a promising agent for bioremediation of PAH-contaminated soils, such as heavy oil waste (HOW). The bioaugmentation of PAH degraders by the bioremediation method (land farming or biopile) can enhance TPH biodegradation and can reduce the residual PAH in bioremedied soil. The mixed culture could enhance the biodegradation of soil contaminated by HOW.

\section{Conclusion}

From the heavy oil waste(HOW) contaminated soil, we successfully investigated the consortium bacteria, which were capable of degrading phenanthrene, 
Table 3. PAH degraders isolated from different environment worldwide

\begin{tabular}{|c|c|c|c|c|}
\hline Sites & Country & Isolates & Compounds & References \\
\hline $\begin{array}{l}\text { Soil } \\
\text { contaminated } \\
\text { by heavy oil } \\
\text { waste (HOW) }\end{array}$ & Indonesia & $\begin{array}{l}\text { Consortium bacteria: } \\
\text { Bacillus altitudinis, Salipiger } \\
\text { sp. PR55-4, Ochrobactrum } \\
\text { anthropi }\end{array}$ & $\begin{array}{l}\text { PAHs, phenanthrene, } \\
\text { dibenzothiophene, and } \\
\text { fluorene }\end{array}$ & This study \\
\hline $\begin{array}{l}\text { Mazut (heavy } \\
\text { residual fuel } \\
\text { oil)-polluted } \\
\text { soil }\end{array}$ & Serbia & Consortium bacteria & $\begin{array}{l}\mathrm{PAH} \text {, the aliphatic, aromatic, } \\
\text { and NSO-asphaltene } \\
\text { fractions, pristane and } \\
\text { phytane }\end{array}$ & Beškoski et al. (2011) \\
\hline $\begin{array}{l}\text { PAH- } \\
\text { contaminated } \\
\text { soil }\end{array}$ & China & Consortium bacteria & PAHs & Mao et al. (2012) \\
\hline $\begin{array}{l}\text { Contaminated } \\
\text { area }\end{array}$ & $\begin{array}{l}\text { United } \\
\text { Kingdom }\end{array}$ & Fungi and bacteria & PAHs & $\begin{array}{l}\text { Bamforth and Singleton } \\
\text { (2005) }\end{array}$ \\
\hline $\begin{array}{l}\text { Sediment } \\
\text { contaminated } \\
\text { by fuel }\end{array}$ & Singapore & Consortium bacteria sediment & $\begin{array}{l}\text { PAHs, naphthalene, } \\
\text { acenaphthene and } \\
\text { phenanthrene }\end{array}$ & $\begin{array}{l}\text { Sherafatmand and } \mathrm{Ng} \\
\text { (2015) }\end{array}$ \\
\hline $\begin{array}{l}\text { Hypersaline } \\
\text { habitat in } \\
\text { Murcia }\end{array}$ & Spain & Salipiger mucescens & - & $\begin{array}{l}\text { Martínez Cá novas et } \\
\text { al. (2004) }\end{array}$ \\
\hline $\begin{array}{l}\text { Hypersaline } \\
\text { habitat in } \\
\text { Murcia }\end{array}$ & Spain & Salipiger muсоsus & Genomic study & Riedel et al. (2014) \\
\hline Deep sea water & China & Salipiger nanhaiensis sp. nov. & - & Dai et al. (2015) \\
\hline $\begin{array}{l}\text { Mangrove } \\
\text { surface } \\
\text { sediment }\end{array}$ & India & Roseovarius sp. & PAHs, phenanthrene & Shahriari et al. (2013) \\
\hline $\begin{array}{l}\text { Sediment of } \\
\text { crooked lake }\end{array}$ & $\begin{array}{l}\text { Indiana, } \\
\text { USA }\end{array}$ & $\begin{array}{l}\text { Mycobacterium flavescens, } \\
\text { Rhodococcus sp. }\end{array}$ & Pyrene & Dean-Rose (2003) \\
\hline $\begin{array}{l}\text { Mangrove, } \\
\text { Huian }\end{array}$ & China & $\begin{array}{l}\text { Bacillus megaterium, Bacillus } \\
\text { cereus }\end{array}$ & $\begin{array}{l}\text { Fluorene, phenanthrene, } \\
\text { fluoranthene, and pyrene }\end{array}$ & Lin and Chai (2008) \\
\hline Soil & Korean & $\begin{array}{l}\text { Acidovorax, Arthrobacter, } \\
\text { Brevibacterium,Burkholderia, } \\
\text { Comamonas, Mycobacterium, } \\
\text { Pseudomonas, and } \\
\text { Sphingomonas }\end{array}$ & Phenanthrene, fluorene & Jong-Su et al. (2009) \\
\hline Soil & Qatar & $\begin{array}{l}\text { Pseudomonas geniculata and } \\
\text { Achromobacter xylosoxidans }\end{array}$ & PAHs & Al-Thani et al.(2009) \\
\hline $\begin{array}{l}\text { Soil samples at } \\
\text { a crop garden } \\
\text { in Wuxi }\end{array}$ & China & $\begin{array}{l}\text { Bacillus subtilis FQ06, } \\
\text { Caulobacter sp. 3-3, } \\
\text { Bacillus pumilus NAPCC-1, } \\
\text { Bacillus sp. CAt2NG, } \\
\text { Stenotrophomonas } \\
\text { maltophilia, Labrys sp. LLQ- } \\
\text { 6, Rhizobium sp. D255c, } \\
\text { Burkholderia sp. lxb-13, } \\
\text { Cytophaga sp. SSL03 }\end{array}$ & $\begin{array}{l}\text { PAHs, phenanthrene, } \\
\text { pyrene, benzo[a]pyrene }\end{array}$ & Ma et al. (2010) \\
\hline $\begin{array}{l}\text { Polluted } \\
\text { sediment } \\
\text { samples } \\
\text { of Caleta } \\
\text { Cordova } \\
\text { harbor }\end{array}$ & Argentina & $\begin{array}{l}\text { Pseudomonas, Marinobacter, } \\
\text { Salinibacterium, and } \\
\text { Brevibacterium }\end{array}$ & PAHs & Isaac et al. (2013) \\
\hline $\begin{array}{l}\text { Apple and pear } \\
\text { fruit }\end{array}$ & Egypt & $\begin{array}{l}\text { Bacillus altitudinis, Bacillus } \\
\text { pumilus }\end{array}$ & Pathogenic of fruit & Elbanna et al. (2014) \\
\hline $\begin{array}{l}\text { Mangrove } \\
\text { sediments in } \\
\text { Hong Kong, } \\
\text { South China } \\
\end{array}$ & China & $\begin{array}{l}\text { Sphingomonas, } \\
\text { Microbacterium, } \\
\text { Rhodococcus }\end{array}$ & $\begin{array}{l}\text { PAHs (fluorene, } \\
\text { phenanthrene, } \\
\text { fluoranthene and pyrene) }\end{array}$ & Li et al. (2009) \\
\hline
\end{tabular}


Table 3. Continued

\begin{tabular}{|c|c|c|c|c|}
\hline Sites & Country & Isolates & Compounds & References \\
\hline Landfarmed soil & Greece & $\begin{array}{l}\text { Genera of Enterobacter, } \\
\text { Ochrobactrum, and } \\
\text { Alcaligenes }\end{array}$ & Petroleum waste & Katsivela et al. (2005) \\
\hline - & $\begin{array}{l}\text { South } \\
\text { Korea }\end{array}$ & Ochrobactrum anthropi SH35B & fungicide chlorothalonil & Kim et al. (2004) \\
\hline $\begin{array}{l}\text { Agricultural } \\
\text { soil and on } \\
\text { the wheat } \\
\text { rhizoplane }\end{array}$ & Germany & $\begin{array}{l}\text { Ochrobactrum anthropi, } \\
\text { Ochrobactrum intermedium, } \\
\text { Ochrobactrum tritici and } \\
\text { Ochrobactrum grignonense }\end{array}$ & - & Bathe et al. (2006) \\
\hline Marine & China & Onchrobactrum sp. BAP5 & benzo[a]pyrene & Yirui et al. (2009) \\
\hline Bloodstream & Malaysia & Ochrobactrum anthropi & - & Rohani and Tzar (2013) \\
\hline $\begin{array}{l}\text { Soil polluted } \\
\text { with } \\
\text { petroleum oil }\end{array}$ & Egypt & $\begin{array}{l}\text { Achromobacter xylosoxidans, } B \text {. } \\
\text { Amyloliquifaciens, }\end{array}$ & Pyrene & Abo-State et al. (2013) \\
\hline
\end{tabular}

dibenzothiophene, and fluorene compounds. From 11 isolates observed, the bacteria having the best performance of three in TPH degradation, emulsification and PAHs degradation are Salipiger sp. MY7, Bacillus altitudinis MY12, and Ochrobactrum anthropi MY13. The three isolated bacteria could be potentially applied as bioremediation agents of heavy oil waste that contains PAHs.

\section{Acknowledgements}

The research funded by the Integrated Laboratory, IPB University, Republic of Indonesia and the company at North Sumatera, Indonesia. The authors would like also to convey their appreciation to the editors and anonymous reviewers for their valuable comments and suggestions.

\section{References}

Abo-State MA et al. 2013. Identification of polycyclic aromatic hydrocarbon degrading bacterial strain and its ability to degrade pyrene. World App Sci J 23:515525. DOI:10.5829/idosi.wasj.2013.23.04.13078

Adhyaru DN et al. 2014. Enhanced production of cellulase-free, thermo-alkali-solvent-stable xylanase from Bacillus altitudinis DHN8, its characterization and application in sorghum straw saccharification. Biocatal Agric Biotechnol 3:182-190.

Al-Thani RF et al. 2009. Isolation and characterization of polyaromatic hydrocarbons-degrading bacteria from different Qatari soils. African J Microbiol Res 3:761-766.

Arifudin et al. 2016. Bioremediasi tanah bertekstur klei terkontaminasi minyak bumi: aplikasi teknik biopile dengan penambahan pasir.J Pengelolaan Sumberdaya Alam dan Lingk 6:13-19.

Bamforth SM, Singleton I. 2005. Review bioremediation of polycyclic aromatic hydrocarbons: current knowledge and future directions.JChem Technol Biotechnol 80:723736.
Bathe S et al. 2006. Genetic and phenotypic micro diversity of Ochrobactrum spp. FEMS Microbiol Ecol 56:272-280.

Beškoski VP et al. 2011. Ex situ bioremediation of a soil contaminated by mazut (heavy residual fuel oil) - A field experiment. Chemosphere 83:34-40.

Calvo C et al. 2004. Surfactant activity of a naphthalene degrading Bacillus pumilus strain isolated from oil sludge. J Biotechnol 109:255-62.

Cerniglia CE. 1992. Biodegradation of polycyclic aromatic hydrocarbons. Biodegradation 3:351-368.

Charlena C et al. 2010. Carbondioxide production during bioremediation of Heavy oil waste by Landfarming technique. Chem Prog 3:1-5.

Clesceri LC et al. 2005. Standard Method for Examination of Water and Wastewater 21th. Washington: American Public Health Association.

Dai X et al. 2015. Salipiger nanhaiensis sp. nov., a bacterium isolated from deep sea water. Int J Syst Evol Microbiol 65:1122-1126.

Dean-Ross D. 2003. Use Of PAH-degrading bacteria in bioremediation of $\mathrm{PAH}$ contaminated sediments. In: Proceeding of 2nd International Symposium on Contaminated Sediments: Characterization, Evaluation, Mitigation/Restoration. Quebec City: Management Strategy Performance. pp. 252-257.

Doi Y et al. 2009. Novel denitrifying bacterium Ochrobactrum anthropi YD50.2 tolerates high levels of reactive nitrogen oxides. Appl Environ Microbiol 75:5186-5194.

Elbanna K et al. 2014. Characterization of Bacillus altitudinis as a new causative agent of bacterial soft rot.JPhytopathol. 162:712-722.

El-Sayed WS et al. 2003. Isolation and identification of a novel strain of the genus Ochrobactrum with phenoldegrading activity. J Biosci Bioeng 96:310-312.

Esakkiraj P et al. 2012. Solid-state production of esterase using fish processing wastes by Bacillus altitudinis AP-MSU. Food Bioprod Process 90:370-376.

Hiraishi A et al. 1995. Polymerase chain reaction amplification and restriction fragment length polymorphism analysis of 16S rRNA genes from methanogens. J Ferment Bioeng 79:523-529.

Isaac P et al. 2013. Indigenous PAH-degrading bacteria from oil-polluted sediments in Caleta Cordova Patagonia Argentina. Int Biodete Biodegr 82:207-214. 
Johnson V et al. 1992. Bioemulsifier production by an oleaginous yeast Rhodotorula glutinis IIP-30. Biotechnol Lett 14:487-890.

Jong-Su S et al. 2009. Bacterial degradation of aromatic compounds. Int J Environ Res Public Health 6:278-309.

Katsivela E et al. 2005. Bacterial community dynamics during in-situ bioremediation of petroleum waste sludge in landfarming sites. Biodegradation 16:169-180.

Kim YM et al. 2004. Glutathione-dependent biotransformation of the fungicide chlorothalonil. J Agric Food Chem 52:4192-4196.

Lin Y, Cai LX. 2008. PAH-degrading microbial consortium and its pyrene-degrading plasmids from mangrove sediment samples in Huian China. Mar Pollut Bull 57:703-706.

Li $\mathrm{CH}$ et al. 2009. Vertical distribution and anaerobic biodegradation of polycyclic aromatic hydrocarbons in mangrove sediments in Hong Kong, South China. Sci Total Environ 407:5772-5779.

Ma B et al. 2010. Isolations and consortia of PAH-degrading bacteria from the rhizosphere of four crops in PAHcontaminated field. In: Proceeding of 19th World Congress of Soil Science, Soil Solutions for a Changing World 1-6 August 2010. Brisbane: Australian Society of Soil Science. pp. 63-66.

Mao J et al. 2012. Bioremediation of polycyclic aromatic hydrocarbon-contaminated soil by a bacterial consortium and associated microbial community changes. Int Biodeter Biodegr 70:141-147.

Martínez-Cánovas MJ et al. 2004. Salipiger mucescens gen. nov., sp. nov., a moderately halophilic, exopolysaccharide producing bacterium isolated from hypersaline soil, belonging to the a-Proteobacteria. Int J Syst Evol Microbiol 54:1735-1740.

Picher DG et al. 1989. Rapid Extraction of Bacterial Genomic DNA with Guanidium Thiocyanate. Lett Appl Microbiol, 8:151-156

Riedel Tet al. 2014. Genome sequence of the exopolysaccharideproducing Salipiger mucosus type strain (DSM 16094T), a moderately halophilic member of the Roseobacter clade. Stand Genomic Sci 9:1331-1343.
Rohani AHS, Tzarm MN. 2013. Ochrobactrum anthropi catheterrelated bloodstream infection: The first case report in Malaysia. Med J Malaysia 68:267-268.

Rosenberg E, Ron EZ. 1998. Bioremediation of petroleum contamination. In: Crawford RL, Crawford DL (Eds.). Bioremediation Principles and Application. Cambridge: Cambridge University Press. pp. 100-124.

Shahriari MM et al. 2013. Isolation, identification and optimization of phenanthrene degrading bacteria from the coastal sediments of nayband bay. Jundishapur J Microbiol 6: e13816. DOI:10.5812/jjm.13816. Sherafatmand M, Ng HY. 2015. Using sediment microbial fuel cells (SMFCs) for bioremediation of polycyclic aromatic hydrocarbons (PAHs). Bioresource Technol 195:122-130.

Shivaji S et al. 2006. Bacillus aerius sp. nov., Bacillus aerophilus sp. nov., Bacillus stratosphericus sp. nov. and Bacillus altitudinis sp. nov., isolated from cryogenictubes used for collecting air samples from high altitudes. Int J Syst Evol Microbiol 56:1465-1473. DOI:10.1099/ ijs.0.64029-0

Syakti AD et al. 2013. The bioremediation potential of hydrocarbonoclastic bacteria isolated from a mangrove contaminated by petroleum hydrocarbons on the Cilacap coast Indonesia. Bioremed J 17:11-20.

Veeranagouda Y et al. 2006. Complete mineralisation of dimethylformamide by Ochrobactrum sp. DGVK1 isolated from the soil samples collected from the coalmine leftovers. Appl Microbiol Biotechnol. 71:369375.

Yirui WU et al. 2009. Isolation of marine benzo[a]pyrenedegrading Onchrobactrum sp. BAP5 and proteins characterization. J Environ Sci 21:1446-165.

Zhang Ret al. 2005. Diversity of organophosphorus pesticidedegrading bacteria in a polluted soil and conservation of their organophosphorus hydrolase genes. Can J Microbiol 51:337-343. 